\title{
The Changes of Economic Structure and Poverty of Women Migrant Worker in Majangtengah Village
}

\author{
${ }^{1}$ KEPPI SUKESI, ${ }^{2}$ JEDDA AYU INGGRIDA \\ ${ }^{1}$ Brawijaya University, Faculty of Agriculture, Agribusiness Department (Jl.Veteran, Malang), Indonesia, \\ ${ }^{2}$ Brawijaya University Campus II, Faculty of Agriculture, Agribusiness (Jl. Pringgodani, Kediri), Indonesia \\ email: 1'keppi_s@yahoo.com; 2 jedda1891@gmail.com
}

\begin{abstract}
The problem of poverty in the rural area of Java is a structural and cultural problem in multidimensional aspects. This research attempts to discern the women migrant workers (WMW) contribution to change their origin, the village they live, so that the WMW family is able to fulfill the needs for a worthy life and later increases the welfare of the village. This research was conducted in Majangtengah Village, Dampit, Malang District. It analyses the economic and poverty condition using a mixed-method, both qualitative and quantitative. The poverty level in the village of sender's of WMW has changed over 30 years. There is no longer poverty in this village which can be seen from the resident house, source of drinking water, facilities of village infrastructure, including the means of worship and Islamic religious school, Madrasah. The WMW has a substantial contribution to their village. There is no unemployment; the children can get their education; the husband can create jobs outside the farm such as being a driver, open stalls/shops, make handicrafts from wood/bamboo, and establish a productive household business.
\end{abstract}

Keywords: economic structure, poverty, women migrant worker

\section{Introduction}

Since 1970, research on poverty has been conducted, especially in the rural area of Java; one of which is research by Sajogyo (2002) that focuses on food and nutrition which then produces the food and adequacy level seen from the fulfillment of family and community nutrition. The quantitative measurement conducted by Sajogyo results in the criteria of poverty measurement known as the poverty line which describes the household expenditure estimated roughly equivalent to $240 \mathrm{~kg}$ rice per capita for rural areas, and $360 \mathrm{~kg}$ of rice/capita in one year for urban areas. $B K B B N$ (National Family Planning Coordinating Board) completes the criteria by viewing the housing condition and public bathing, washing, and toilet facilities (MCK).

The problem of poverty in rural Java is a multidimensional-structural and cultural problem that also includes politics, social, economics, assets and natural resources, psychology, etc. Poverty is a situation when a community is vulnerable, helpless, and unable to convey their aspirations. In a poor rural area, the households cannot fulfill their basic needs, have limited income sources, and have incomplete basic facilities and infrastructure such as inadequate housing and slum environment. Poverty is not merely a condition of food and productive assets shortages, but also the limitation of participation in public activities and development (Sukesi, 2015).

Another problem arising is a large number of unemployment which implies the low income of a person/family due to the imbalance number of job vacancies and working forces (Haryati, 2009). Haryati (2009) states that this condition forces the Indonesian workforce to seek employment opportunities abroad. Basically, there have been some previous researches that focused on analyzing the phenomena of Indonesia labor which states that they are the biggest foreign exchange contributor for Indonesia.

The previous researches were more focused on how women immigrant workers work abroad to be able to improve the

Received: 2019-07-24, Revised: 2019-08-28, Accepted: 2019-12-23

Print ISSN: 0215-8175; Online ISSN: 2303-2499. DOI: https://doi.org/10.29313/mimbar.v35i2.4899

Accredited Sinta 2 based on the decree No.10/E/KPT/2019 until 2024. Indexed by DOAJ, Sinta, Garuda, Crossreff, Dimensions 
family's welfare without seeing the impact on the village condition. Irawaty and Wahyuni (2011) state that unskilled women in the rural area choose to work abroad because it is considered as a good opportunity to boost the WMW'sfamily economy. Another study was conducted by Setiadi (2001) who focused on the impact of migration on a family's life, especially on the change in control and consistency of social values affecting the husband's appreciation of women's role in the household. Therefore, this research examines not only the aspect of change to the well-being of WMW households but also the influence of women working abroad on the change of village condition.

In limestone mountainous area of South East Java, a poverty change or transformation happens through the phenomena of women migrant workers which show a greater number than men. Sukesi et al. (2017) find there are social, economic, and cultural transformations driven by women migrant workers. During this time, almost $75 \%$ Indonesian workers work in the informal sector such as a housekeeper, babysitter, as well as elderly nurses, and only $25 \%$ work in the formal sector of oil palm plantation, electronics, and automotive industry, as well as trading services (Bank Indonesia, 2008). During 2011-2014 there was a positive development related to the distribution of Indonesian migrant work placement. Based on data from PUSLITFO BNP2TKI-National agency for the placement and protection of Indonesian labor (2014), it showed that there was a gradually increasing percentage of the formal Indonesian migrant placement and reduction in percentage for informal WMW placement. In 2011, the percentage of formal WMW placement was $45 \%$ and in 2014 rose to $58 \%$; while the percentage of informal WMW placement in 2011 was $55 \%$ and in 2014 dropped to $42 \%$.

According to data from BNP2TKI (2016), East Java ranks number two as the province which sends the most of WMW overseas reaching 6.2 million people, and Malang Regency is number two WMW sender area in Indonesia. So far, the WMW service and protection offered by the Government is still focused on migrant workers who are going to the destination country. This is due to a number of cases of violence against WMW during their work in the destination country and cases of illegal WMW. While the attention of government related to the return of former migrant workers to Indonesian origin or known as former Indonesian migrant workers are still low. The problem faced by former migrant workers is still related to their role as women since there is a gap in UU number 39 the year 2004 regarding the processes of recruitment, departure, and return to the place of origin (Rahayu and Munir, 2012).

The majority of workers sent abroad are female because the employment available is housework for women. Nevertheless, in certain areas such as Dampit, the workforce that works abroad consists of $60 \%$ of women and $40 \%$ of men (Disnaker, 2010). The majority of them work in non-formal sectors. The departure of WMW working abroad should have a social-economic impact on their families, especially those who have married. Indonesia's economy increases because of strong communities with low poverty, however, the phenomenon of poverty figures in Indonesia in 2015 was increased compared to 2014 which estimated about 0.78 million people (BPS, 2016).

Indonesian economic and social conditions that are not ready to prepare Indonesian people in the field of employment cause the poverty rate to increase. It worsens by the enactment of a moratorium on WMW sending abroad in 2017, especially for informal and unskilled sectors. Since WMW in Indonesia is quite a lot, if those who have been abroad do not have sufficient expertise, they will be returned to Indonesia and it will have fatal impact on the increasing number of poverty in Indonesia. From the research results on the former WMW, it shows that not all returning WMW is ready to work independently in the country because the work ethic built overseas is as a worker not an entrepreneur. They also brought no money when they returned to Indonesia due to the absence of savings during work (Sukesi, et al., 2012; Wijaya, 2012). This happened because not all women of former migrant workers and their families were able to utilize their money gained from working abroad as an entrepreneurial capital.

The history of gender stereotyping in society is caused by the lack of gender insight of WMW to change their traditional tasks and domestic functions. WMW think that household's works remain their responsibility as women. They work traditionally with low entrepreneurial insight so that they need socio-economic protection (Sukesi, 2008). The impact of working as a WMW is the improvement of their knowledge and experience and identity, however, it is 
also found that many WMW do not return to their original regions and there is no further information of their existence. The positive impact of WMW for families is the household economy, the creation of capital in the countryside, the independence of the children left at home; but it is also found juvenile delinquency as a result of the absence of one of their parents' care. The results of Pallikadavath's research (2015) in Southern Malang showed that WMW's departure affects the family of husbands, parents, and children. It is economically increasing, but the diversion of parenting roles to grandparents raises the workload of grandparents, husband's double roles, and children temporarily separated from his mother. In addition, there were some cases of broken homes because wife and husband live separately. However, the positive impact of WMW on the village can be seen, especially, on physical appearances such as housing, the building of mosques, and the formerly poor environment turned into the inhabited environment. Therefore, to a certain extent, women migrant workers succeeded in reducing or negating poverty in their home village.

Indonesian migrant workers contribute greatly to the welfare of their families, and at the macro level it also increases the foreign exchange which made them known as "foreign exchange hero". On the other hand, the enormous contribution of migrant workers in the delivery of remittance has not been supported by the readiness and capacity of migrant workers and their families in utilizing remittance for a productive business that can become a source of family's economic income. Most of the remittance is used for consumption needs (daily necessities); while another utilization is used to build a house and pay debts or for children's school needs. Former Indonesian migrant workers use a smaller part of their wages for productive activities than for the consumptive activities. Considering the rural change that takes place very quickly, it is necessary to research the impact on the poverty of individuals, households and communities in the migrant village sender.

The results of the study conducted by Sukesi (2012) show that the WMW who have an entrepreneurial insight will be able to manage their work as an entrepreneurial capital. The remittance as the foreign exchange has been surpassed the government's expectation and lowers poverty in developing countries (Adams \& Page, 2005). However, apparently, the research results of Ghosh (2005) states that the impact (of remittance) on the development of the country is merely a myth. Nevertheless, for the social-economic impact of the family, the results of the research conducted by Rosalinda (2012) found that socio-economic remittance are invaluable for WMW's family life and only WMW with a clear vision that could make use of remittance well and sustainably, otherwise, those who have no clear plan will only spend their money on consumption needs and things they frequently find. However, some studies have found that remittance has an impact on household income in the Philippines (Semyonov \& Gorodzeisky, 2005) and Nepal (Thieme \& Wyss, 2005) as well as the development of micro-business in Mexico (Woodruff \& Zenteno, 2007).

Results from a previous study on women Indonesian migrant as a contract of domestic workers conducted by Wijaya et al. (2014) revealed that the majority of WMW came from villages and poor families, low educational conditions and social status, and had no professional working skills. It is clear that their condition in the recipient country is very vulnerable so that protection is needed started from the recruitments, placement, place of work, until returning back to the country (Safaat, 2002; Wijaya, et al., 2014). In addition, Sukesi et al. (2005) examine the impact of international migration on WMW family structures. It indicates that there is a change in the WMW family structure. Without the presence of a mother figure in the family (a married WMW), the family care function and nurture of the child are taken over by the husband or other household members. However, the function of a mother seemed irreplaceable that can be seen from children's inhibited education, lack of affection, and the onset of behavior change of children and even husbands. Therefore, it gives a psychic burden on BMI in the workplace. In the first years, for example, their minds are still on the family they left behind.

Women who work abroad generally have families that struggle to fulfill their basic daily needs. Being a WMW is the best option and is considered to make more money than working in the village of origin. However, the weakness or lack of skill makes most of the WMW work in the informal sector. Remittance in form of money transfer becomes an aspect in the well-being of WMW which significantly affects the use of financing for education, family in total, and daily living expenses households (Mafruhah, et al., 2012). 
The wealth gained from working as migrants looks like a funfair which lost in one night, very short and temporary happiness. The departure of Indonesian migrants was driven by economic reasons; therefore, on the first departure, they have a big hope to make money to solve the problems of the household. Economic impacts are felt in the form of better housing conditions, capable of buying motorcycles and get home furnishings. The next departure is still for consumptive needs, and for the third contract, they use it to earn business capital. However, less fortunate WMW still cannot build a house and create business capital.

\section{Research Methodology}

This study used a mixed-method, both qualitative and quantitative with a case study design conducted in WMW village sender in Malang Regency. The data was collected through structured interviews carried out in two stages with the poor WMW and the community leaders, Focus Group Discussion (FGD), the study of life history and analysis on the secondary data from the village, and related documents. To answer the first objective, the data was analyzed quantitatively; while for the second objective, the data were analyzed comparatively between migrant and non-migrant families and continued with a qualitative narrative. The impact analysis was done in a qualitative descriptive to assess the socio-economic changes in the village's macro, comparing the migration phenomena and the current state. At the micro-level, the researcher analyzed the historical development of women's socioeconomic migrant workers.

Respondents and research informants were chosen by some characteristics, namely: (1) mapping toward the households of former female migrant workers; (2) migrant workers who have returned to Malang Regency in Indonesia, and the comparator is household which has no family member of a migrant worker. From two criteria, the informant will be chosen purposively with the criteria classified as a poor family, relative to the criteria in the village of origin. The number of respondents was 30 WMW and 5 key informants consisting of villagers and community leaders.

\section{Results and Discussion}

Women migrant workers (WMW) in Majangtengah village has been a migrant worker since they were young, starting from the age of 14 with the length of contract ranging from $1-5$ years until more than 11 years. There are four main working destination countries of WMW in figure 1.

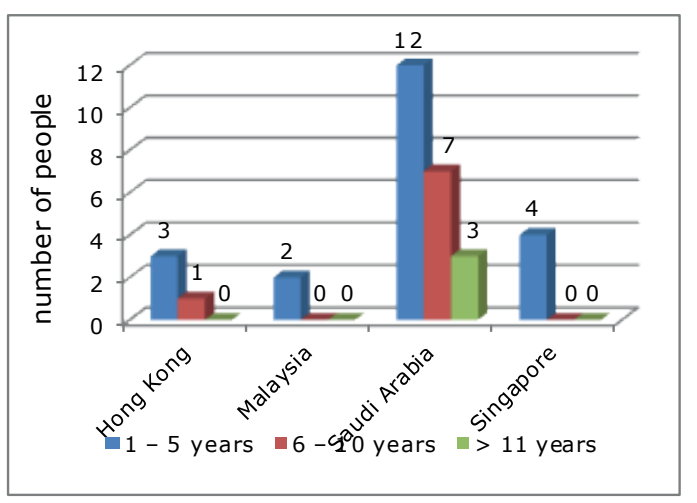

Figure 1. Destination Countries and Age of WMW

The top destination of WMW is Saudi Arabia with a short working period of 1-5 years as much as 12 people and a long period of time of more than 11 years as much as 3 people. Salary or wages received by WMW in Saudi Arabia amounted to 1,200 - 1,300 Riyal per month or Rp $4,562,797$ to Rp.4,943,031. Knowing this phenomenon, many WMW chooses Saudi Arabia as their working destination because there is a bilateral agreement between the Indonesian government and the Saudi Arabian government for WMW protection. In addition, they also may get a chance to perform Hajj or Umrah.

The majority of remittance from WMW to their family is used to build or repair the house. The WMW expect when they return to Majangtengah village, they can have and see the results of their work for fulfilling a primary necessity in the form of a convenient place to live because in the village there is still a thought that the success of a person is seen from how big and luxurious the house is. The type of house also becomes one of the indicators of welfare and/or WMW success. The type of house is seen from the four aspects of the wall, floor, ventilation, and bathing, washing, and toilet facilities in figure 2,3 , and 4 .

Generally, the remittance is spent to renovate WMW's houses. Now it is common to find a house with a wall made of solid materials (estimated 29 people have it or $96.67 \%$ ) and ceramics (estimated 18 people have it or $60.00 \%$ ) and every house has been completed with ventilation and private bathing, washing, and toilet facilities. Today, 
it is rare to find a house without ventilation and uses public bathing, washing, and toilet facilities. The asset also becomes an indicator of measuring poverty. This capital asset refers to vehicles of either a car or a motorcycle. The possession of this asset can be more than one asset, shown in figure 5 .

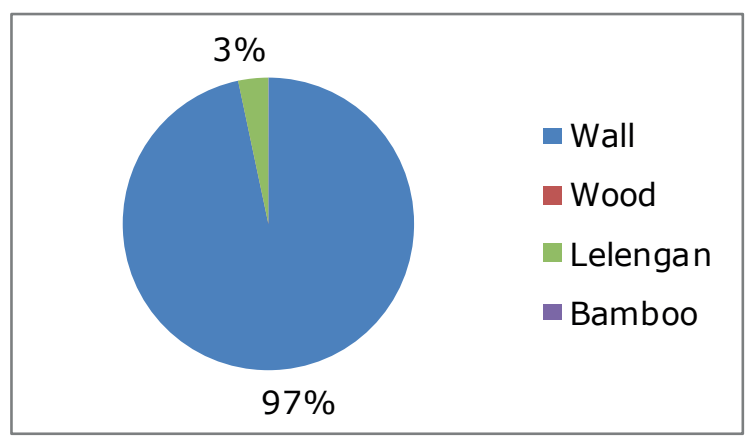

Figure 2. Type of house is seen from the wall

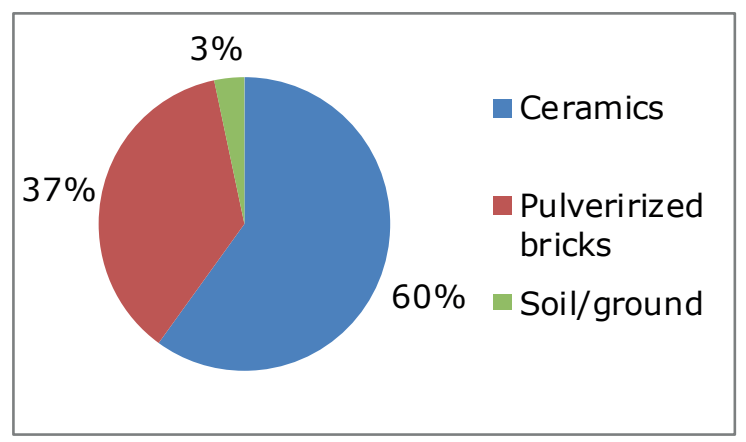

Figure 3. Type of house is seen from the floor

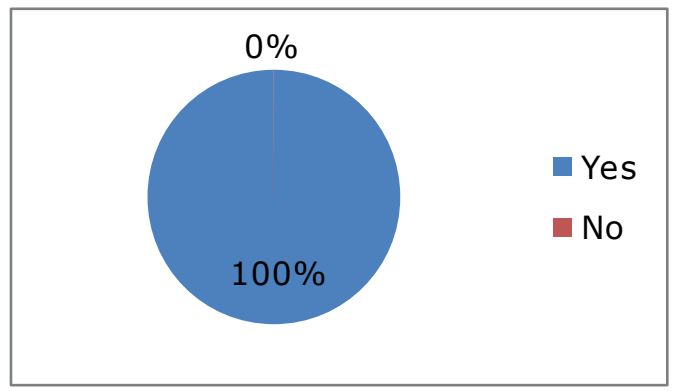

Figure 4. Type of house is seen from ventilation

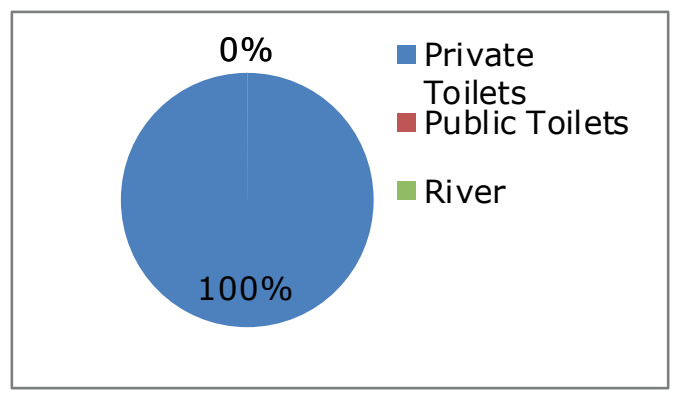

Figure 4. Type of house is seen from bathing, washing, and toilet facilities

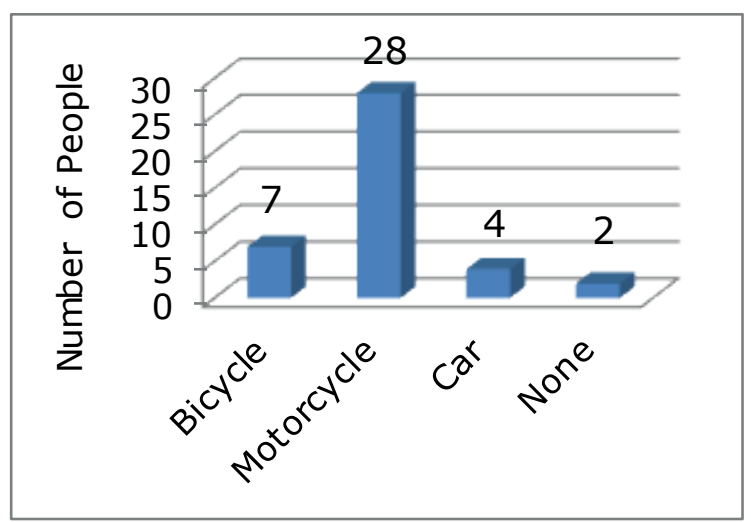

Figure 5. Type of assets of WMW

Based on the diagram above, it can be seen that the common asset possessed by WMW is a motorcycle of 28 units (68.29\%) and a bicycle of 7 units (17.07\%). One WMW has not only one type of asset but two or even more.

\section{The History of Migration in Majangtengah Village}

According to the key informant, the existence of WMW began in the 1980s when a sponsor $(P T)$ informed or offered the opportunity to work overseas as a WMW. The sponsors did door to the door marketing technique. They also provided brochures when there was a big event in Majangtengah. As a result, the information about employment as WMW overseas was widespread in Majangtengah. Then, the sponsors negotiated with the women of prospective migrants. Every effort is made so that they qualify to be migrant workers, ranging from passport forgery and changing the year of birth. The big "lure" of wages encouraged the women in Majangtengah Village to take the decision to become a WMW because they want to help improve the life and economy of their households since they thought that working in Majangtengah was less fulfilling the daily needs, the needs of school children, and other needs. Saudi Arabia becomes top of the country destination for WMW because there is a close religious relationship between Indonesia and Saudi Arabia. There were many neighbors or residents said they performed Umrah, even though they did not return for years as they worked as WMW in Saudi Arabia. Thus, many WMW went to Saudi Arabia with the intention to be able to worship. 
There are many cases that WMW did not register to the office of Majangtengah Village. Lately, the WMW departure to Saudi Arabia has been ended for various reasons, so that the destination country for WMW candidates of Majangtengah which originally only Saudi Arabia has to extend to various other countries. Nowadays, most women are WMW in Taiwan, Singapore, and Hongkong; while most males become migrant workers in Taiwan and Korea. For Korea's destination, the registration can be completed through GNP2TKI-an institution similar to the regional office of the Manpower Department, but it does not cooperate with that department. The majority of WMW work in Taiwan as elderly nurse and housekeepers. Meanwhile, WMW in Hongkong and Singapore mostly works as housekeepers.

Generally, the departure of WMW abroad is assisted by PJTKI (Indonesia Manpower Agency) or known by the community Majangtengah as ' $P L$ ' or 'sponsor'. In general, the reason for working as a WMW for women in Majangtengah village is to help the economy of the household to be better and able to fulfill daily needs. Their departure led to a change of work patterns before and after becoming WMW. Gumelang (2019) shows the condition of household poverty affects women in international migration. In addition, there are other originating factors that affect a person to do an international migration, namely factor of the origin, a factor of the destination area, and factors of each individual. Low wage and the presence of foreign labor agencies become the biggest influence factors of origin with the percentage of each is $30 \%$. Furthermore, regarding the factors originating from outside the region or the target area, the percentage of the largest influence is the reason fora conducive environment estimated at $43 \%$. As for the factors derived from each individual, the largest percentage is influenced by the need for at $43 \%$. Gumelang (2009) also analyzes the use of remittance which shows two types of patterns: consumption and investment. The majority use of remittance for consumption patterns is to fulfill dietary needs with a percentage of $25.64 \%$, while for investment pattern is spent on educative cost with a percentage of $48.33 \%$.

\section{The Changes of Economic Structure}

One of the striking and physically visible changes is the village's economic structure. Prior to the migration of women to work abroad in 1987, Majangtengah Village was a plateau, dry, rainy, and hilly village. Two hamlets are rugged hilly villages with a slope of more than 45 degrees. In two other villages that do not get irrigation, farmers planted coffee. In the irrigation area (from the tributary) farmers planted rice. Meanwhile, the inland region is inhabited by poor farmers living in simple houses that lined up along the village road.

Following the expanding migration abroad, where women worked as domestic workers in Saudi Arabia and men worked as construction workers, the village faces changed gradually, starting with migrants build their houses from woods into the wall of bricks or ceramic houses, tiled floors and quite good ventilation. These migrants are mostly women because much-needed employment is a household worker. Saudi Arabia has another attraction, which are migrants can perform Hajj or Umrah, a very high value for the Muslim community in Majangtengah. However, when the migrant woman has ended her working contract and returned to hervillage, many returned to its original status as a housewife.

The money sent by the WMW from the destination country to the origin country is called remittance or known by the inhabitants of Majangtengah as a 'kiriman'. The remittance has to be transferred to the family because it is the WMW responsibility to help the economy of the household left, showed in figure 6 and 7.

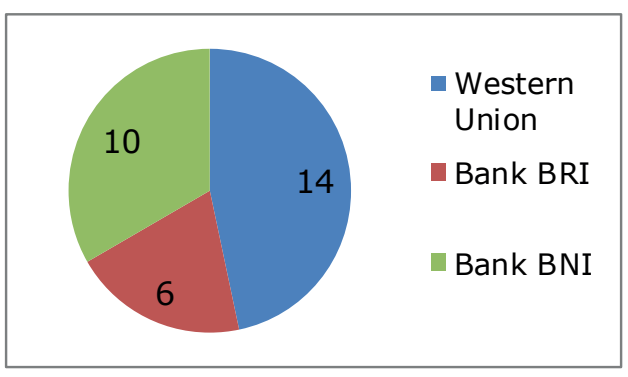

Figure 6. Ways to send remittance

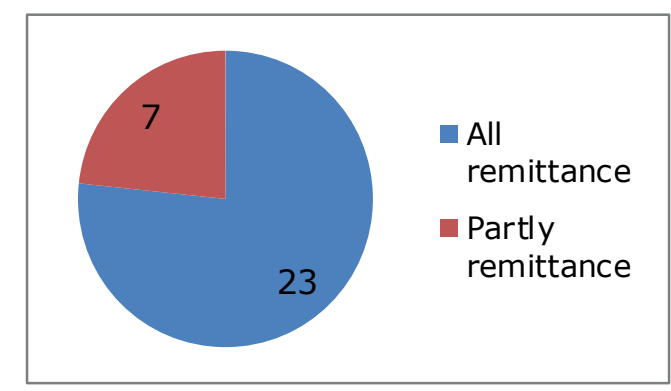

Figure 7. The portion of remittance sent to the family Source: Lestari (2019)

Remittance is delivered in three ways, 
namely via Western Union, Bank BRI, and Bank BNI. Based on the data above, 14 people $(46.67 \%)$ send it through Western Union, 6 people (20\%) send it through Bank BRI, and 10 people $(33.33 \%)$ send it through Bank $B N I$. However, the amount of money sent by WMW is also different. There is a WMW who sends out all her money and there is also a WMW who sends only a portion of her wages. The numbers of WMW who send out all their money are 23 people or $76.67 \%$. This is because all of WMWs' needs have already fulfilled by employers, while the WMW who send only a portion of their wages are 7 people or $23.33 \%$. They do that because they keep half of their wages for fulfilling their needs and for savings. It can be concluded that the majority of the informants send all their wages to their villages to meet the needs of their families. The average amount of the remittance sent is around Rp. 1 million up to Rp.3.6 million.

The remittance is also used for business capital. Therefore, there is a significant change that emerged with the number of small-scale female entrepreneurs who have new businesses that have not existed in Majangtengah before, which is the processed food business, birdcage crafts, klompen (wooden shoe), cafes, shops, stalls, etc. While their wives working abroad, husbands also got remittance and used them for productive businesses such as opening stores, raising chicken, broiler sellers, farmers, goat farmers, etc, been show in Table 1.

Basically, migrant workers are not only women but also men. However, this research highlights the WMW(female migrant worker). The change of male jobs in Majangtengah Village is one of the consequences of the WMW phenomenon, where remittance from abroad is used by the husband/family to fulfill daily needs. In the time when there is no WMW phenomenon, the majority of husbands/men occupations consist of 4 types: peasants, farmers, ranchers, and craftsmen (making Bakiak and Klompen). After becoming a WMW, the men/husband jobs become more diverse because of the capital gained from remittance, such as opening a shop, being broiler seller, making a birdcage, being bird breeder, etc, has been show in table 2 .

Women's jobs before becoming WMW are more diverse than men, such as students, housewives, domestic workers, farm laborers, etc. However, after working abroad, many women in Majangtengah decided to become a WMW. Women who return to Indonesia and do not get back to foreign countries decide to use the remittance to open stores or start a business, such as a broiler seller, apparel business, goat farmers, etc.

\section{Poverty Condition inMajangtengah Village}

The condition of poverty in Majang tengah has decreased in the last 30 years as stated by the informant:

" ... Once there were a lot of farmworkers in this village. Other jobs were small merchants who trade coconuts, banana;

Table 1

Types of Male Jobs in Majangtengah Village

\begin{tabular}{lll}
\hline Gender & Previous job before WMW & Jobs after $\mathbf{W} \mathbf{M W}$ \\
\hline Man & Farm laborer & Traditional intermediary services for selling cows \\
& and goats & Shops owner \\
Farmer & Bird breeder \\
Craftsmen of Bakiak, Klompen & Farmers \\
Breeder & Labor factory \\
& Construction Worker \\
& Pandebesi/Welder \\
& Farmworker \\
& Massage \\
& Broiler seller \\
& Birdcage maker \\
\hline
\end{tabular}

Source: Processed of primary data (2018) 
MIMBAR, Vol. 35 No. $2^{\text {nd }}(2019)$

Table 2

Types of Female Jobs in Majangtengah Village

\begin{tabular}{cll}
\hline Gender & \multicolumn{1}{c}{ Previous Job before WMW } & \multicolumn{1}{c}{ Jobs after WMW } \\
\hline Woman & Farm laborer & Merchant \\
& Farmer & Farmers \\
& Housewife & Farm laborer \\
Student & Housewife \\
Coffee picker/selector & Broiler seller \\
Housekeeper & Apparel business/Apparel shop \\
Self-employed & Chicken Lathe (poultry miling) \\
& Goat Farmer \\
& laundry worker \\
\hline
\end{tabular}

Source: Processed of primary data (2018)

they usually departed after Fajr prayers. "In addition to work, the condition of poverty can be seen from the limited number of vehicles ownership. Initially, people used to walk to go everywhere. The children commute on foot and were not picked up by their parents. There were many houses made of bamboo (gedeg). Another poverty indicator is a dietary population. For poor people, the staple foods were rice mixed with corn or cassava and seldom eat meat or eggs. They consumed meat only on Ied Adha (Festival of Sacrifice in Islam), and consume eggs when there is a hajatan-particular event (party).

At that time, there was no Public Health Center (PUSKESMAS) in Majangtengah village. People made traditional drugs or jamu if they got sick. Within 30 years, by the phenomenon of migration of women to work abroad, then the economic structure of the population changed which also changed the condition of poverty. Currently, Majangtengah Villagehasa PUSKESMAS and Integrated Service Post (POSYANDU). Currently, the existence of farm laborers is greatly reduced to 860 people for men and 834 people for women. The total ownership of the motorcycle has started evenly; there are 41 motorcycles with one household capable of having 1-3 types of motorcycle so that many parents pick up their children using motorcycles or cars.

The majority of house conditions are having a wall of bricks and plaster floors. There is also increased consumption of rice, meat and egg. The average level of education was elementary school graduates or not graduating from elementary school, but nowadays, the community's education has reached senior high school and can even complete college and undergraduate education. Senior high school graduates in Majangtengah is currently 1,816 men and 1,376 people women; while for college graduates (D1, D2, D3) are 40 men and 18 women. The highest graduates in Majangtengah are S1 (undergraduate) and S2 (Post-graduate) estimated by 27 men and 12 women.

It can be said that the economic structure of the village changed by the presence of WMW phenomenon. The work structure used to be farmers-laborers- limited traders, but now it turns into farmers-few of farm laborers-merchants-craftsmen. The income level of farmer households, during the wife working abroad, is between Rp.3 million up to Rp.5 million per month. From the gross income, WMW are able to send remittance to their family ranging from Rp. 1 million up to Rp3.6 million per month for consumption needs, for children's school, and saving. For the successful WMW, the results of working abroad are not only used to meet the primary needs of food but also for the needs of children's school and open business or investment. Through this system, the return of WMW is able to overcome poverty, to have a decent household, have enough money and no need to return to be a woman migrant worker.

\section{The Women Migrant Worker Impacts on Poverty Conditions in Majangtengah Village}

In general, the impact of WMW on the condition of poverty in Majangtengah can be mapped as in Table 3. 
KEPPI SUKESI, et al. The Changes of Economic Structure and Poverty of Women Migrant Worker in...

Table 3

The WMW Impacts on The Condition of Majangtengah Village

\begin{tabular}{lll}
\hline Village Criteria & Before & After \\
\hline Village poverty conditions & Many poor people & Reduced \\
Staple Food & Corn, Gaplek-processed cassava, rice & Rice \\
Village irrigation System & River, Tadah hujan-rainfed & River \\
Clean water Condition & Well & self-service and regional water \\
& & Supply company (PDAM)
\end{tabular}

Housing conditions

A. Migrant workers

The average house is made of bamboo Now it is a nice house, with very simple design

large, with a wall of bricks

\begin{tabular}{|c|c|c|}
\hline B. Non-Migrant workers & $\begin{array}{l}\text { The average house of bamboo and still } \\
\text { simple }\end{array}$ & $\begin{array}{l}\text { The house is small and still } \\
\text { simple }\end{array}$ \\
\hline Village type & self-service & self-service \\
\hline
\end{tabular}

Source: Processed of primary data (2018)

The number of poor people in the village is greatly reduced. Those who used to be farm laborers become farmers or tenants, and now the main food is rice. Although the irrigation system in the village remained from the river and tadah hujan (rainfed water), farmers are able to buy fertilizer and medicines as needed, so that the plant business will be more productive. The needs of clean water of households are used to be sourced from wells, and now there is a self-service PAM. Housing that used to be less decent, now it's a nice building and livable. Nevertheless, the status of this village has not changed, from the former village of self-service (Swakarya), now still remains as self-service, been shown in figures 8 and 9 .

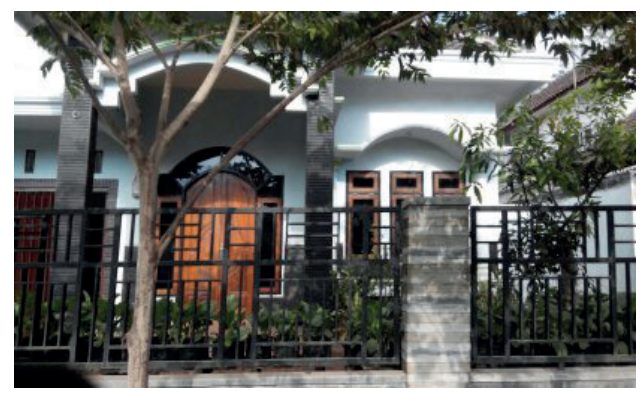

Figure 8. House of WMW

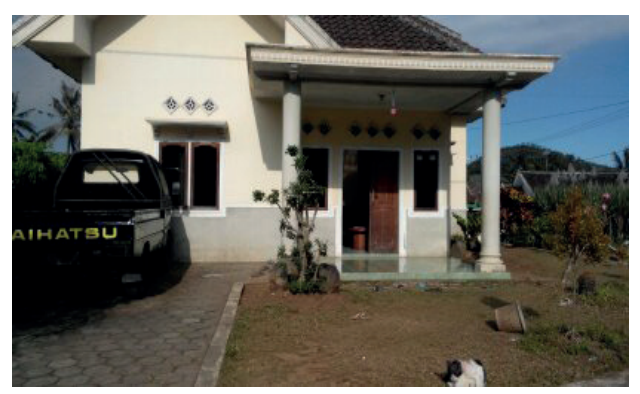

Figure 9. House of WMW

\section{Conclusions}

The village economic structures change takes place on employment and the income source of the population. Jobs are more diverse, in agriculture both as owners and craftsmen, and outside the farm as traders, services provider, and artisans. The land mastery system changed in Majangtengah Village has changed ground mastery status. The farm laborers and narrow land turned into farmers or land tenants.

The poverty condition in the WMW sender village has changed over 30 years. The village that once appeared the face of poverty is now changed, judging by the conditions of the inhabitants' houses, drinking water resources, facilities of village infrastructure, including the means of worship and schoolMadrasah.

The impact of women migrant workers on poverty conditions in the village of origin is quite apparent. There is no more unemployment, WMW children are able to attend advanced school, the left husband is able to create jobs outside the farm, especially as a driver, owner of stalls/shops, artisans of handicrafts of wood and bamboo, and being a productive household business.

\section{Acknowledgment}

Gratitude is addressed to Rector of Brawijaya University who has funded this research through Hibah Guru Besar scheme in 2018 and to the DRPM Ministry of Research Technology and Higher Education by the research scheme 2019. 


\section{References}

Adams, R.H. and Page, J. (2005). Do International Migration And Remittances Reduce Poverty In Developing Countries. World Development, Vol. 33, No. 10, pp. 1645-1669

Badan Pusat Statistik. (2016). Kabupaten Malang dalam Angka. BPS. Malang

Bank Indonesia. (2008). Hasil Survey Nasional Pola Remitansi TKI. Bank Indonesia. Jakarta

BNP2TKI. (2016). Data Penempatan Dan Perlindungan Tenaga Kerja Indonesia Periode Tahun 2015. Jakarta

Dinas Tenaga Kerja dan Transmigrasi Kabupaten Malang (Disnaker). (2010). Pemberdayaan Buruh Migran Melalui Remitansi dan Perluasan Kerja untuk Memperkuat Pembangunan Ekonomi Daerah

Ghosh, Buddhadeb and De, Prabir. (2005). Investigating The Linkage Between Infrastructure and Regional Development in India. Journal of Asian Economics 15 pp. $1023-1050$

Gumelang, Nando A.P. (2019). Pengaruh Kemiskinan Terhadap Keputusan Migrasi Internasional (Studi Kasus : Tenaga Kerja Wanita Purna di Desa Majangtengah, Kecamatan Dampit, Kabupaten Malang). Dibawah bimbingan Prof. Dr. Ir. Keppi Sukesi, MS. Fakultas Pertanian Universitas Brawijaya

Haryati, E. (2009). Remitansi Tenaga Kerja Indonesia: Dampaknya Terhadap Inflasi Dan Kontribusinya Terhadap Peningkatan Kualitas Hifup Masyarakat. Ekuitas Vol. 13, No. 3, Hal. 388 - 405

Irawaty, T., and Wahyuni, E. S. (2011). Migrasi Internasional Perempuan Desa Dan Pemanfaatan Remitan Di Desa Pusakajaya, Kecamatan Pusakajaya, Kabupaten Subang, Propinsi Jawa Barat. Sodality: Jurnal Transdisiplin Sosiologi, Komunikasi dan Ekologi Manusia. Vol. 5, No. 3, Hal. 297 - 310

Lestari, Octavia Arum Budi. (2019). Pola Pemanfaatan Remitan serta Dampaknya terhadap Pengentasan Kemiskinan pada Rumah Tangga TKW Purna (Studi Kasus di Desa Majangtengah, Kecamatan Dampit, Kabupaten Malang). Di bawah bimbingan Prof. Dr. Ir. Keppi Sukesi, MS. Fakultas Pertanian Universitas Brawijaya

Mafruhah, I., Sarsito, Totok; and Gravitiani, Evi. (2012). The Welfare of the Indonesian Migrant Workers (TKI) in the Land of a Malay Nation : A Socio-Economic Analysis.
Southeast Asian Journal of Social and Political Issues, Vol. 1, No. 2, pp. 246 271

Pallikadavath, S. (2015). The Social and Economic of International Female Labour Migration on Left-Behind Husband : Case Study of East Java, Indonesia. Research Collaboration PB Centre Brawijaya University and Newton Institutional Link Grant

Rahayu, D., and Munir, M. (2012). Alternatif Kebijakan Peraturan Daerah Perspektif Gender Bagi Buruh Migran Perempuan di Madura. Mimbar Hukum Vol. 24, Nomor 3, Oktober 2012, Hal 377 - 569

Rosalinda, H. (2012). Social Remittance as impact of International Migration : The Retrun Migrant Women in East Java, Indonesia. GSID Nagoya University

Safaat, R., dkk. (2002). Menggagas Kebijakan Pro BMI : Model Kebijakan Perlindungan BMI ke Luar Negeri. Kabupaten Blitar. Kerjasama BAPPEDA Kabupaten Blitar dengan Pusat Penelitian Hukum dan Gender, FH UB

Sajogyo. (2002). Sosiologi Pedesaan. Gadjah Mada Press. Yogyakarta

Semyonov, M. and Gorodzeisky, A. (2005). Labor migration, remittances and household income: A comparison between Filipino and Filipina overseas workers. International Migration Review, Vol. 39, No. 1, pp. $45-68$

Setiadi. (2001). Masalah Reintegrasi Sosial Dan Ekonomi Migran Kembali. Populasi, Vol. 12, No. 1, Hal. $21-35$

Sukesi, K. (2005). Dampak Migrasi Internasional Terhadap Keluarga. Laporan Penelitian, tidak diterbitkan.

Sukesi, K. (2008). Kajian dan Pelatihan Kewirausahaan bagi PPM Purna. Laporan Penelitian, tidak diterbitkan

Sukesi, K. (2015). What Happens to the Family When Women Migrate? An International Collaborative Programme on The Impact of Female International Migration on Poverty, Children, Elderly, Spouse and Fertility in East Java. Newton Institusional Link Grants, Melalui Universitas Brawijaya

Sukesi, K., dkk. (2017). Changes in SocioEconomic and Cultural Behavior of Female Indonesian Migrant Workers. HABITAT Vol. 28, N0. 3, Tahun 2017, Hal. $114-121$

Thieme, S., and Wyss, S. (2005). Migration patterns and remittance transfer in Nepal: A case study of Sainik Basti in western Nepal. International Migration, Vol. 43, No. 5, pp. 59-98 
KEPPI SUKESI, et al. The Changes of Economic Structure and Poverty of Women Migrant Worker in...

Wijaya, H.R, and Sukesi, K. (2012). Model Perekayasaan IPTEKS Sosial Bagi Wanita Pekerja Kontrakan Luar Negeri di Tempat Kerja: Kebijakan Perlindungan Tenaga Kerja Indonesia di Hongkong. Direktorat Jenderal Pendidikan Tinggi, Kementerian Pendidikan dan Kebudayaan, Melalui DIPA Universitas Brawijaya

Wijaya, H.R; Sukesi, K., and Suhariningsih. (2014). Strategi Penguatan Profesionalisme Perempuan Calon
Buruh Migran Internasional (BMI) Untuk Negara Tujuan Hong Kong. Direktorat Jendral Pendidikan Tinggi, Kementerian Pendidikan dan Kebudayaan melalui DIPA Universitas Brawijaya

Woodruff, Christopher and Zenteno, Rene. (2007). Migration networks and microenterprises in Mexico. Journal of Development Economics, Vol. 82, No. 2, pp. 509-528. 